\title{
Pulmonary tuberculosis in a patient with rheumatoid arthritis undergoig immunosuppressive treatment: case report ${ }^{*}$
}

\author{
Tuberculose pulmonar em paciente com artrite reumatoide durante tratamento imunossupressor: \\ relato de caso
}

\author{
Sandro Ceratti ${ }^{1}$, Talita Rombaldi Pereira ${ }^{2}$, Sílvio Fontana Velludo ${ }^{2}$, Leonardo Pereira Dalcim² ${ }^{2}$ Gladston \\ Oliveira Machado ${ }^{3}$, Hélio Kiyoshi Hasimoto ${ }^{4}$
}

Ceratti S, Pereira TR, Velludo SF, Dalcim LP, Machado GO, Hasimoto HK. Pulmonary tuberculosis in a patient with rheumatoid arthritis undergoig immunosuppressive treatment: case report. Radiol Bras. 2014 Jan/Fev;47(1):60-62.

Abstract Rheumatoid arthritis is a disease which characteristically affects the joints. Because it is an autoimmune disease, immunosuppressive drugs are widely used in its treatment. The present case report illustrates the association of immunosuppressive treatment with the development of opportunistic infections in a 64-year-old patient.

Keywords: Rheumatoid arthritis; Pulmonary tuberculosis; Immunosuppressive therapy.

Resumo A artrite reumatoide é uma doença que, caracteristicamente, acomete as articulações. Por ser autoimune, drogas imunossupressoras são amplamente utilizadas em seu tratamento. Este caso ilustra a associação do tratamento imunossupressor com o desenvolvimento de infecções oportunistas em uma paciente de 64 anos de idade.

Unitermos: Artrite reumatoide; Tuberculose pulmonar; Terapia imunossupressora.

\section{INTRODUCTION}

Rheumatoid arthritis is an autoimmune inflammatory systemic disease characterized by involvement of the synovial membrane of peripheral joints. It is estimated that rheumatoid arthritis is prevalent in $0.5-1.0 \%$ of the general population, predominantly in women and with highest incidence in the age range between 30 and 50 years $^{(1)}$. However, pleuropulmonary manifestations are most frequently observed in men ${ }^{(2)}$. The main characteristic of rheumatoid arthritis is the symmetrical involvement of both small and large joints, most frequently affecting hands and feet ${ }^{(1)}$. The early diagnosis of such a condition may improve the prognosis, avoiding disease progression to critical stages and allowing a long and effective treatment ${ }^{(3)}$.

Intrathoracic alterations are numerous and variable and most frequently include interstitial pulmonary fibrosis, bron-

* Study developed at Pontifícia Universidade Católica de São Paulo (PUC-SP) Conjunto Hospitalar de Sorocaba, Sorocaba, SP, Brazil.

1. Titular Member of Colégio Brasileiro de Radiologia e Diagnóstico por Imagem (CBR), Invited Professor at School of Medicine, Pontifícia Universidade Católica de São Paulo (PUC-SP), Physician Assistant at Conjunto Hospitalar de Sorocaba, Radiologist at RadMed - Radiologia e Serviços Médicos SS, São Roque, SP, Brazil.

2. MDs, Trainees in Radiology and Imaging Diagnosis at Conjunto Hospitalar de Sorocaba, Sorocaba, SP, Brazil.

3. PhD, Full Professor of Radiology and Imaging Diagnosis, Coordinator of Program of Taining in Radiology and Imaging Diagnosis, School of Medicine - Pontifícia Universidade Católica de São Paulo (PUC-SP), Sorocaba, SP, Brazil.

4. Master, Professor, School of Medicine - Pontifícia Universidade Católica de São Paulo (PUC-SP), Thoracic Surgeon, Hospital Santa Lucinda, Sorocaba, SP, Brazil.

Mailing Address: Dra. Talita Rombaldi Pereira. Rua dos Andradas, 175, Bloco 8, ap. 21, Jardim Faculdade. Sorocaba, SP, Brazil, 18030-175. E-mail: rptali@yahoo. com.br.

Received February 4, 2013. Accepted after revision July 15, 2013. chiectasis, bronchiolitis obliterans and pleural thickening. Pulmonary hypertension may be also found. Other less common pulmonary manifestations include organizing pneumonia, diffuse alveolar damage, lymphoid hyperplasia (follicular bronchiolitis), lymphoid interstitial pneumonia and rheumatoid nodules ${ }^{(2)}$. In rheumatoid arthritis, bone alterations of the chest wall include bone resorption in the distal region of clavicles and erosive arthritis of the shoulders ${ }^{(4)}$.

Interstitial pneumonitis and fibrosis represent the most common pulmonary manifestations in rheumatoid arthritis. In fact, alterations in the pulmonary function compatible with interstitial fibrosis have been reported in up to $40 \%$ of patients with rheumatoid arthritis but, in more than half of those patients, radiographic findings are normal. Findings of interstitial fibrosis at radiography are reported in approximately $5 \%$ of patients with rheumatoid arthritis, and in $30-40 \%$ at high-resolution computed tomography. Such a complication is most frequently observed in men aged between 50 and 60 years, and typically may present a distribution pattern with predominance of alterations in the pulmonary periphery and bases $^{(5)}$.

Rheumatoid nodules are characterized by dense areas of fibrinoid necrosis pathologically identical to those found in the subcutaneous tissue. Typically, the nodules measure between $0.5 \mathrm{~cm}$ and $5 \mathrm{~cm}$, and generally are located in the periphery of the middle and upper lobes, and may be either single or multiple ${ }^{(2)}$. Pulmonary nodules may present cavitation, increase in size, and spontaneous resolution over time; and new nodules may develop while the older ones resolve. Nodules rupture in the pleural space, pneumothorax, pleural effusion or empyema rarely occur ${ }^{(6)}$. Fungal coloniza- 
tion of cavitating rheumatoid nodules is extremely uncommon. Such nodules may frequently be confused with other diseases, among them tuberculosis.

\section{CASE REPORT}

A 64-year-old woman undergoing treatment for rheumatoid arthritis with immunosuppressive drugs for 50 years, among them corticotherapy and methotrexate. At a short term after the use of anti-TNFs (tumor necrosis factor blockers/ inhibitors) in association with the treatment, the patient started presenting respiratory symptoms and was submitted to radiography and computed tomography. Figure $1 \mathrm{dem}-$ onstrates ill defined opacities at radiography. At high-resolution computed tomography (Figure 2), the presence of nodules is observed, some of them cavitated, inferring diagnostic hypotheses of opportunistic infections, among others. Figure 3 demonstrates other juxtapleural nodules as supplementary findings.

With basis on the symptoms and images, the option was for resection of some nodules. The specimens were sent for histopathological analysis which demonstrated the lung parenchyma with a well delimited area involved by a lymphohistiocytic inflammatory process associated with rare multinucleated giant cells. The lesion center was replaced by caseous necrotic tissue. All such characteristics have determined the diagnosis of pulmonary tuberculosis.

Upon the diagnosis, the use of anti-TNFs was suspended and the treatment for pulmonary tuberculosis was instituted. Currently, the patient remains under imaging follow-up and is stable.

\section{DISCUSSION}

The use of immunosuppressive drugs is related to the development of opportunistic infections. The inhibition of cytokines such as TNF-alpha, particularly in cases where it is associated with other immunosuppressive drugs (methotr-

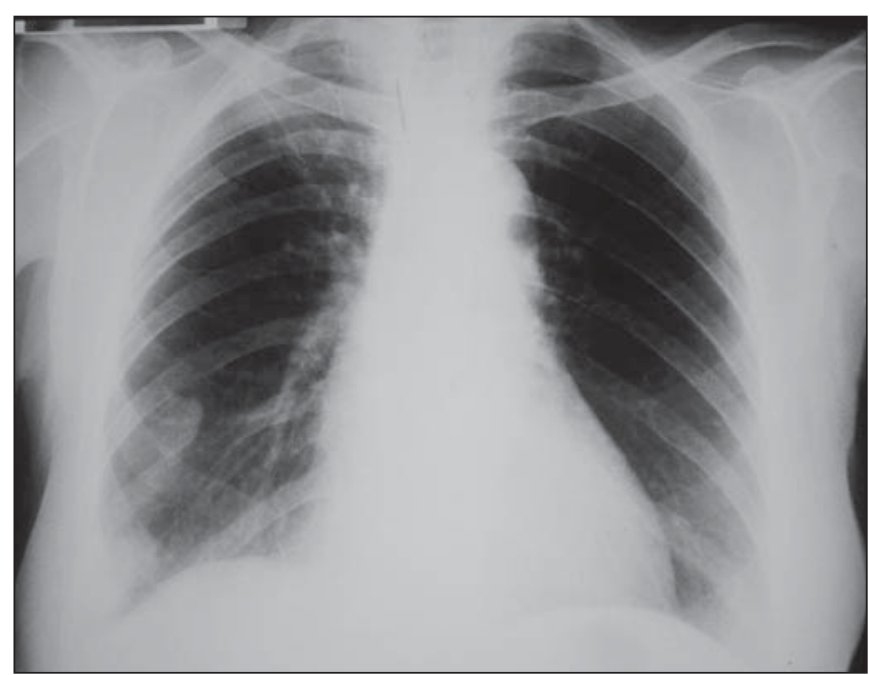

Figure 1. Posteroanterior chest radiography demonstrating nodular opacities projecting over the lower field of the right lung and another ill-defined opacity projecting over the region of the ipsilateral apex.

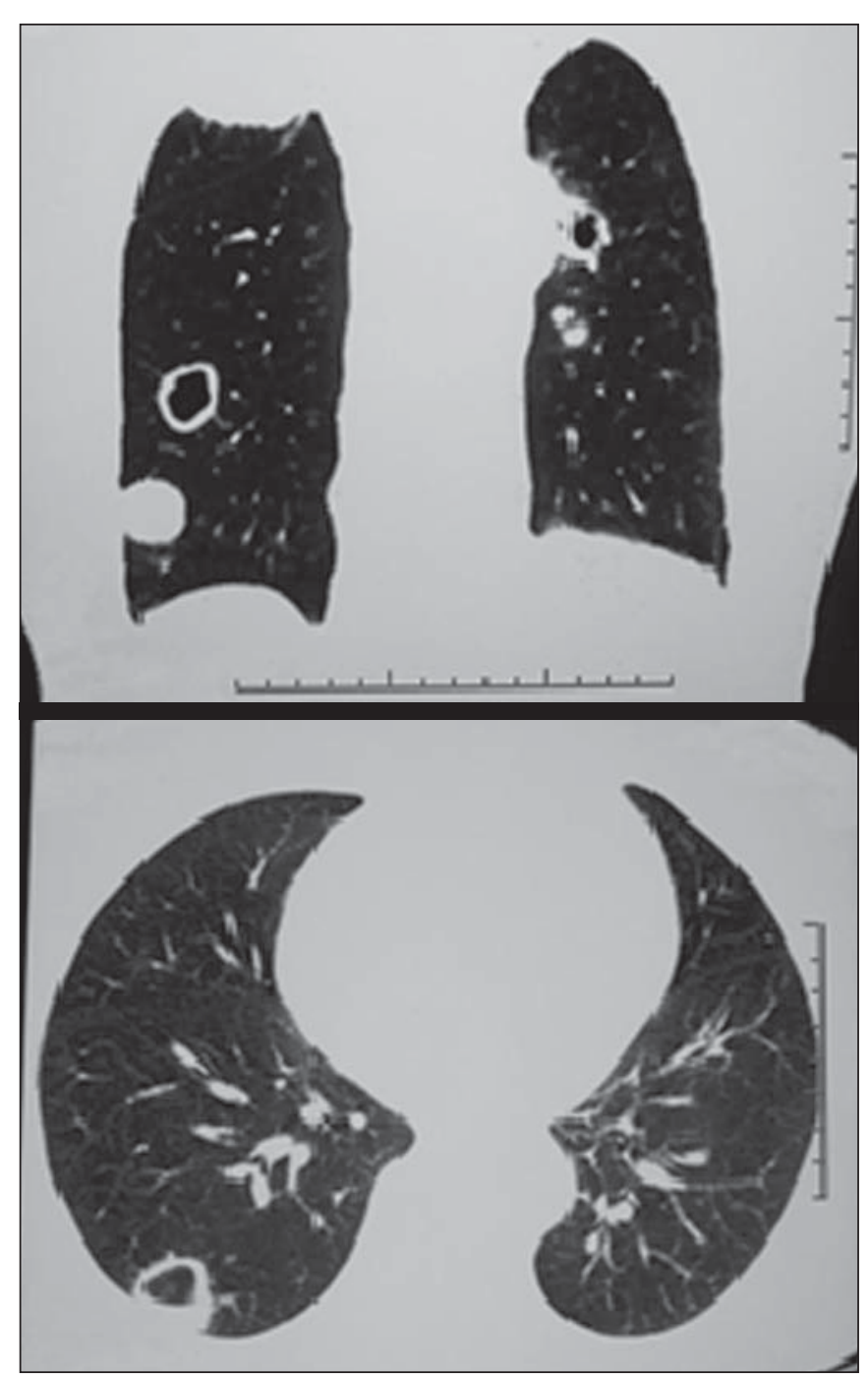

Figure 2. Coronal and axial high-resolution computed tomography demonstrating cavitation with thickened walls, a mural nodule in the right lung base and another in the upper field of the left lung. Additionally, a round-shaped, well-delimited nodule is observed in the right lung base, besides a ill delimited opacity in the ipsilateral lung apex.

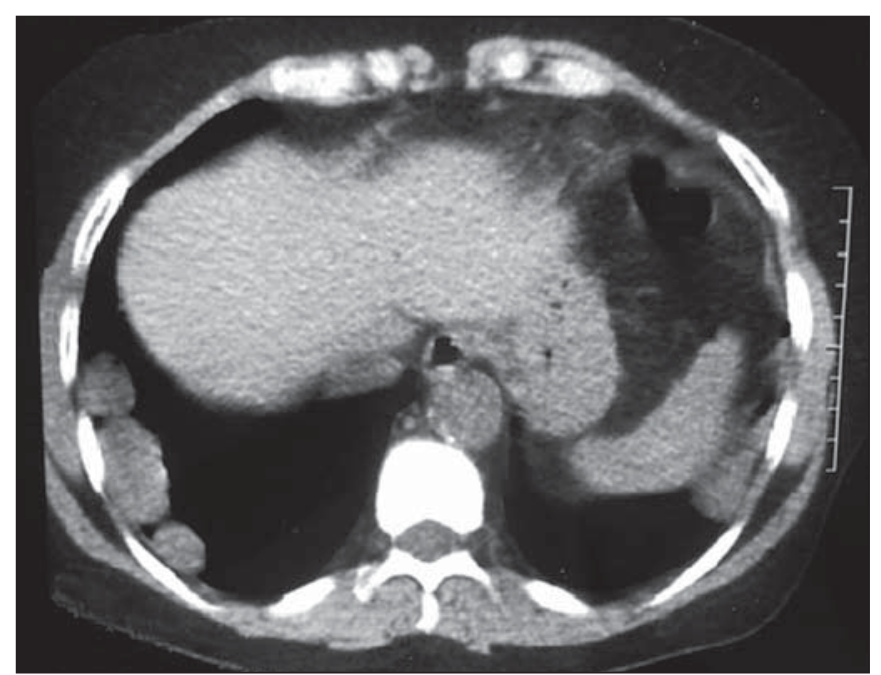

Figure 3. Non contrast-enhanced, axial computed tomography demonstrating three hypodense, round-shaped and well delimited juxtapleural pulmonary nodules at right and one at left. 
exate and corticoids), reduces the resistance to infections caused by intracellular pathogens such as tuberculosis bacillus ${ }^{(7)}$. The association between tuberculosis and use of corticosteroids in immunosuppressive doses is well documented. On the other hand, the use of low doses of corticoids causes higher incidence of infections in cases of combination with other drugs such methotrexate $e^{(7)}$.

In the decade of the 1990s, the use of anti-TNFs for treatment of rheumatoid arthritis modified the rheumatology practice since it allowed for a more appropriate management of the disease in cases refractory to treatment with conventional DMARDs (disease modifying antirheumatic drugs), consequently, with a remarkable improvement in the quality of life of such patients. However, the use of anti-TNFs gave rise to a problem which was considered as resolved in many developed countries, namely, the high risk of reactivation of latent tuberculosis infection ${ }^{(8)}$, since the drug destabilizes the natural protection against the tuberculosis bacillus in infected patients, thus facilitating its multiplication.

\section{REFERENCES}

1. Mota LMH, Cruz BA, Brenol CV, et al. Consenso 2012 da Sociedade Brasileira de Reumatologia para o tratamento da artrite reumatoide. Rev Bras Reumatol. 2012;52:135-74.

2. Silva CIS, Müller NL. Doenças do colágeno e espondilite aquilosante. In: Silva CIS, D'Ippolito G, Rocha AJ, et al., editores. Tórax. Série Colégio Brasileiro de Radiologia. São Paulo: Elsevier; 2011. p. $515-$ 26.

3. Narváez JA, Narváez J, De Lama E, et al. MR imaging of early rheumatoid arthritis. Radiographics. 2010;30:143-65.

4. Mayberry JP, Primack SL, Müller NL. Thoracic manifestations of systemic autoimmune diseases: radiographic and high-resolution CT findings. Radiographics. 2000;20:1623-35.

5. Kim EA, Lee KS, Johkoh T, et al. Interstitial lung diseases associated with collagen vascular diseases: radiologic and histopathologic findings. Radiographics. 2002;22 Spec No:S151-65.

6. Capobianco J, Grimberg A, Thompson BM, et al. Thoracic manifestations of collagen vascular diseases. Radiographics. 2012;32:33-50.

7. Mangini C, Melo FAF. Artrite reumatoide, terapia imunossupressora e tuberculose. Rev Bras Reumatol. 2003;43(6):xi-xv.

8. Marques CDL, Duarte ALBP, Cavalcanti FS, et al. Abordagem diagnóstica da tuberculose latente na artrite reumatóide. Rev Bras Reumatol. 2007;47:424-30. 